\title{
NOTES ON THE PROGRESS OF CHEMISTRY-II.
}

\author{
BY LYMAN C. NEIVELL, PH. D.
}

The first article in this series was published in Vol. II, No. 4 (October, 1902, page 229).

International Catalogue of Scientific Literature, D-Chentistry (Interuat. Cat. Sci. Lit., 2 (1902); pt. 1, pp. 468.) "This catalogue is being prepared by a central bureau in London under the directorship of H.F. Morley and by twenty-nine regional bureaus in different countries. The supreme control of the catalogue is vested in an international convention, to meet in London in 1905, 1910, and every tenth year thereafter. In the interval between successive meetings the administration is vested in an international council consisting of one renresentative from each regional bureau. The plan adopted provides for author and subject indexes for the different branches of science, which have been, arranged in seventeen groups. This volume, for which E. Goulding is referee, is an incomplete index of the literature of chemistry during 1901, the publication of the second part of the volume being promised in a few months."

Platinum. (1) Recent Advances in Our Knowledge of the Metals of Platinum Group, Amer. Chem. Jour., Jan., 1904, page 63. (2) Geological Relations and Distribution of Platinum and Associated Metals, Bulletin 193 (Reprint), U. S. Geol. Survey. The first article is a report by Prof. James Lewis Howe on the contributions to this subject made during 1897-1903. It comprises about twenty pages and is a complete resumé. "Localities and output have undergone comparatively little change," though several regions have been studied, especially the Tulameen district in British Columbia. An account of this last locality forms a large part of the second article. "Platinum in the form of spirrylite $\left(\mathrm{Pt} \mathrm{As}_{2}\right)$ seems to be a constant accompaniment of the Sudbury, Ontario, nickel ores, and is concentrated in the matte to the extent of about 50 grams of platinum per ton of nickel." In the Bulletin by Professor Kemp there is a review of all the occurrences of platinum. "He inclines to the op:nion that platinum has been deposited from fusion."

"No subject connected with the platinum metals has recently attracted more attention than the work of Bredig and his followers on colloidal platinum as an inorganic ferment. In 1898 an apparent solution was obtained of a dark wine color, which did not clear up in weeks and which was very active in promoting those so-called catalytic actions which have long been known to be bronght about by finely divided platinum. It was soon found that this solution, now known as colloidal platinum, possesses many of the properties of an organic ferment, and, like the latter, is so affected by the presence of certain salts and other substances that it is no strained application of the term to speak of its being poisoned." 
Professor Kemp's bulletin besides giving many facts about the composition of platinum ores, contains six plates and nine jllustrations (two of the plates being colored), and a map of the platinum region of British Columbia. It can be obtained without cost from the Director of the U. S. Geol. Survey, Washington, D. C.

Quariz Apparatus,-In a review of the progress in industrial chemistry Thorp says: "The manufacture of chemical vessels of fused quartz has reached a successful issue in Germany. Dishes and crucibles are now articles of commerce. Owing to the very low coefficient of expansion of quartz it is little affected by extremes of heat and cold, and its inertness makes it useful for acid vessels, pump valves, etc. It withstands water, acids and neutral salts, but not alkaline liquids and dry oxides at high temperatures. Being transparent to ultra violet rays of the spectrum, fused quartz is suggested for vacuum tubes." Quartz vessels can now be obtained of American dealers. (Jour. Amer. Chem. Soc., Feb., 1904.)

Nichel-Steel-By Crittenden Marriott. Sci. Amer., July 11, 1903, page 23. Alloys of these metals have been investigated by Charles $\mathrm{E}$. Guillaume, of the International Bureau of Standards.

Regarding the properties of alloys of nickel and steel, a writer in the For um for July-September, 1903, page 60, says: "One of the most remarkaile of these is the fact that certain alloys of steel and nickel possess much lower coefficients of expansion than either of the constituent metals. The alloy which has attracted the greatest attention is the minimum-expansion alloy, containing thirty-six per cent of nickel; this has only one-fourteenth the expansion of platinum for any given increase of temperature, thus being extremely useful for the construction of standards of length, measuring tapes, clock pendulum bars and the like. Thus M. Guillaume states that a unit of the thirty-six per cent alloy, one kilometer long, varies in length less than $0.4 \mathrm{~mm}$. in passing from $0^{\circ}$ to $20^{\circ}$ C.! A more recent application of this property is found in the possibility of varying the proportions of steel and nickel so as to produce an alloy having the desired coefficient of expansion. In the construction of incandescent electric lamps and other apparatus requiring metal connections to be fused into glass, it has been found necessary to use platinum wire because that metal expands and contracts almost exactly the same as glass. M. Guillaume las succeeded in making a nickel-steel alloy having precisely the same coefficient of expansion as that of glass, and wire of this alloy is used to replace platinum in many places in which the fusion in glass is necessary."

Orygen-Acetylene Blon'pipe--Forum. July-September, 1903, page 64. This new apparatus is "practically identical with the oxy-hydrogen blowpipe, with the exception of the substitution of acetylene gas for the hydrogen. The high calorific power of the acetylene renders it possible 
to produce in this way temperatures exceeding $4,000^{\circ} \mathrm{C}$., while the readiness with which acetylene can be generated from calcium carbide and water obviates the difficulty of procuring hydrogen. The heat produced by the oxygen-acetylene blowpipe is so great that any of the metals used in the arts may be readily fused, while the welding of steel or iron may be effected with ease and certainty."

Atomic Weights.-The table of atomic weights for 1904, prepared by the international committee is the same as that for 1903 with two exceptions, viz.: Cæesium becomes 132.9 and cerium $140.25(O=16)$. (Jour. Amer. Chem. Soc., Jan., 1904, page 1.)

Dianonds.-Artificial diamonds have recently been made by an interesting process. "By using a modification of the Goldschmidt process, the magnesium, aluminum and oxides being taken in such proportion as to form the natural matrix of the diamond, von Hasslinger has succeeded in converting finely divided graphite into clear, octahedral diamonds 0.5 $\mathrm{mm}$. in diameter. The diamonds are formed by slow cooling in absence of any considerable pressure." (Journal American Chemical Society, December, 1903, page 1284.)

Apropos of the above we should note the following item, which appeared in Science for February 12, 1904:

"It has been very generally accepted that Moissan prepared diamonds synthetically by chilling an iron rich in carbon, the supposition being that in the interior of the mass of iron, solidified on the exterior, the pressure on solidification must be intense, and that under these conditions the carbon crystallized in the form of diamond. This position is very strongly attacked by $\mathrm{C}$. Combes in the Moniteur Sclentifique. In this paper he argues that Goepert and Friedel have found plant remains in diamonds, sluwing that the crystals must have been formed at a temperature below at least $772^{\circ}$. At the temperature of fused cast iron the diamond is converted into graphite. The diamonds supposed to have been formed by Moissan were doubly refracting and were not diamonds. Moissan's analyses of his crystals were insatisfactory for damonds. Finally Friedel has proved that stich a mass of iron as was used by Moissan really contracts on cooling instead of expanding and hence the supposed pressure was not present. Thus it appears to Combes impossible that Moissan has prepared diamonds."

Bacteria and the Nitrogen Problem-By George T. Moore. Yearbook U. S. Dept. Agr., 1902, page 333. Nitrogen-fixing Bacteria. By J. S. Lipman. Pop. Sci. Mo., December, 1902, page 137. These articles confirm previous views regarding the fixation of atmospheric nitrogen by bacteria, though both note the fact that nitragin-the artificial culture of the bacteria used to inoculate the soil-is no longer an article of commerce, its use not having met the expectation of the projectors.

The first article can be obtained, as a reprint, from the Secretary of Agriculture, Washington, D. C. 
Since the above articles were published, the matter has taken an expected and propitious turn. We quote from President Remsen's address on Scientific Investigation and Progress (Pop. Sci. Mo., February, 1904, page 291): "According to the most reliable estimates the saltpeter beds will be exhausted in thirty or forty years. Is there a way out? Dr. Frank (and others) show that there is. In the air there is nitrogen enough for all. The plants can only make a limited use of this directly. For the most part it must be in some form of chemical combination as, for example, a nitrate of ammonia. The conversion of atmospheric nitrogen into nitric acid would solve the problem, and this is now carried out. But Dr. Frank shows that there is another way of geting the nitrogen into a form suitable for plant food. Calcium carbide can now be made without difficulty and is made in enormous quantities by the action of a powerful electric current upon a mixture of coal and lime. This substance has the power of absorbing nitrogen from the air, and the product (calcium cyonamide) thus formed appears to be capable of giving up its nitrogen to plants, or, in other words, to be a good fertilizer. It is true that the subject requires further investigation, but the results thus far obtained are full of promise."

The teclnical account of this new process is in the Experiment Station Record (U. S. Dept. Agr.), Jan., 1904, page 424, and the four. Ancr. Chem. Soc., Feb., 1904, page 214); a brief account is putlished in Science, Jan. 29, 1904, page 197.

Bricf Bibliography of Radium (popular articles).

(a) Radio-Activity, Harpers, August, 1902, page 357.

(b) Radium and Its Recent Development, Scientific American Supplement, July 25, 1903, page 203,042.

(c) Wonders of Radium, McClures, November, 1903, page 3 .

(d) Spinthariscope, American Journal of Science, July, 1903, page 99.

(e) Home- Mfade Spinthariscope, Scientific American, January ?, 1904, page 8 .

(f) Disintegration of the Radioactive Elements, Harpers, January, 1904, page 297. (This is by Ernest Rutherford, and is one of the most accurate art:cles.)

(g) Radium and Its Mysteries, Scientific American, January 2, 1904, page 9 .

(h) Radium and Its Wonders, Revietw of Revien's, November, 1903, page 585. (Very complete.)

(i) The New Element, Radium, Century, January, 1904, page 451.

(j) Radium and Radioactivity, by Mme. Curie, Century, January, 1903, page 461 .

(k) The Action of Radium, Röntgen Rays and Uttra Violet Light on Minerals and Gems, Science, December 18, 1903, page 769. 